\title{
Exploring the Relationships among Service Qual- ity, Satisfaction, Trust and Store Loyalty among Retail Customers
}

\section{Çerri Shpëtim}

\begin{abstract}
The purpose of the study is to investigate the relationships among service quality, satisfaction, trust, and store loyalty in a retailing context. All these variables have considerable importance on store performance, measured by financial indicators or market ones. The data were collected from a sample of 258 students at two universities in Albania, during the first quarter of 2012. The items included in the survey measured the variables of the study as well as demographic characteristics of the sample. Confirmatory factor analysis (CFA) and structural equation modeling (SEM) were used to evaluate the hypotheses regarding relationships among model constructs. All the hypotheses developed in the study were positively confirmed, reinforcing the theory and previous research on this field. The study also reveals interesting implications in service quality, satisfaction, trust, and store loyalty, useful to both academics and practitioners. Managers will find this research helpful in better understanding these variables and their roles on their companies' performance.
\end{abstract}

Key words: Service quality, Satisfaction, Trust, Loyalty, Retailing

\section{INTRODUCTION}

In response to the increasingly competitive marketplace, retailers are continually seeking strategies to insulate and increase profit. These strategies often concentrate on improving service quality, increasing customers' satisfaction and trust, and fostering customers' loyalty. Service quality has gained tremendous attention from managers and academics due to its considerable influence on business performance, cost reduction, customer satisfaction, customer loyalty and profitability (Gummesson, 1998; Sureshchander et al., 2002). Often and more the quality is considered as an investment for company, where the efforts for its improvement result in an increased clientele, increased levels of purchase from existing customers, and a rise in the company's profits (Parasuraman et al., 1985; Reichheld and Sasser, 1990; Rust et al., 1995).

Satisfaction is also a much desired target for businesses, since a satisfied customer is likely to buy more, return to the store and spread positive word-of-mouth opinions to other customers (Anderson, Fornell, \& Lehmann, 1994). Customer satisfaction leads to greater customer loyalty ( Bolton \& Drew, 1993), reduces the costs of future transactions (Reichheld \& Sasser, 1990), positively impacts firm's revenues (Bolton 1998), and minimizes customer defection if quality falters.

Trust involves one person's expectations that another will behave in a certain way (Deutsch, 1958; Schurr \& Ozanne, 1985). Trust between two parties requires that, if one part does not behave as expected, the other party will experience more negative outcomes than if the other does behave as expected (Deutsch, 1958). Trust is considered to be an important element of consumer 
perceptions about brands and companies (Aaker, 1997). Trust is beneficial for both customers and companies: customers benefit through a reduced perception of risk toward service provider and through social benefits derived from a trusting service provider; companies benefit through increased sales, reduced costs, positive word-of-mouth and even employees retention (Moorman et al., 1993; Schurr et al., 1985).

Customer loyalty is considered an important key to organizational success and profit. Firms with large groups of loyal customers have been shown to have large market shares, and market share, in turn, has been shown to be associated with higher rates of return on investment (Raj, 1985; Reichheld \& Sasser, 1990). Dick and Basu (1994) suggest that brand loyalty stimulates positive worth of mouth and makes loyal customers more resistant towards competitive strategies.

The focus of this study is to identify what consumers consider to be important in terms of the services they receive in a retail setting, and to explore possible explanations of consumer attitudes and intentions (customer satisfaction, customer trust, and customer loyalty) due to the perceived services quality. It will also assess the effects that satisfaction has on trust and loyalty, and the effect of trust on loyalty. Thus, the study aims to explore the possible relationships between perceived service quality and consumers' behavioral attitudes and intentions (i.e., customer satisfaction, customer trust, and customer loyalty) in the context of retailing. This will lead to an integrated model which provides a clear structure of service quality and its impacts on customer satisfaction, customer trust, and customer loyalty in the retailing setting. It also permits a development of practical retailers' service improvement programs based on the suggested Service Quality- Satisfaction-Trust-Loyalty model.

\section{THEORETICAL FRAMEWORK AND DEVELOPMENT OF HYPOTHESES}

\subsection{Service Quality}

Service quality has been perhaps the most explored topic in services marketing. Early efforts in defining and measuring quality were mostly centered in the tangible products (goods) sector, while the seemingly more difficult services sector was ignored. Grönroos (1984) notes that service quality delineates two rather distinct facets of the construct: a technical dimension (the core service provided) and a functional dimension (how the service is provided). Product quality was traditionally linked to the technical specifications of goods, with most definitions of quality arising from the manufacturing sector where quality control has received prolonged attention and research (Grönroos, 1990). Garvin (1983) defined quality as something that involves eliminating 'internal failures' (defects before the product leaves the factory) and 'external failures' (defects after product use); while for Crosby (1979), quality is 'conformance to standards'. While these product-based definitions of quality may be appropriate to the goods-producing sector "knowledge about goods quality ... is insufficient to understand service quality" (Parasuraman et al., 1985).

Literature published in the late 1970s and early 1980s provided a clearer understanding of service quality and its measurement. For example, Shostack (1977) and Lovelock (2000) recognized the intangible characteristic of services and that most services are performances rather than objects 
and are experiences rendered, unlike goods which are tangible objects to be possessed. Bowen and Cummings (1990) suggest that "an organization's overall climate of service, the atmosphere or feel of the setting, is very important in shaping both customers' and front-line employees' attitude about the process and outcome of service delivery".

Carmen and Langeard (1980) and Grönroos (1983) have discussed another characteristic of services which makes service quality definition and measurement difficult its simultaneous production and consumption. Particularly in labor-intensive services such as restaurants or retailing, quality is created during the process of service delivery, and in encounters between staff and patrons. This then suggests that an instrument to measure service quality must have adequate means of assessing patrons' perceptions of service quality during these service encounters. A third characteristic of service is its heterogeneous nature, especially in those services with high labor content. This means that service performance will vary from producer to producer, from patron to patron and also from one encounter to the next. Zeithaml (1981) has suggested that the heterogeneous nature of service hinders the consistency of service delivery and thus, assessment of service quality. What the establishment had intended to deliver might be quite different from what the patrons received. An understanding of the characteristics of service is necessary in the selection of an appropriate instrument to measure service quality. Such an instrument needs to accommodate the difficulties raised above and recognize that the quality of services is more difficult for customers to evaluate than the quality of goods, and that quality assessments are made not only on the service outcome, but also on the process of service delivery (Parasuraman et al., 1985).

\subsection{Satisfaction}

During the past decades, customer satisfaction has frequently been advanced to account for customer loyalty (Dick \& Basu, 1994, Oliver 1996; Zeithaml et al., 1996). Oliver (1996) defines satisfaction as the summary psychological state resulting when the emotion surrounding disconfirmed expectations is coupled with a consumer's prior feeling about the consumer experience.

Since the early 1990s, service and satisfaction research has grown to include an emphasis on cumulative satisfaction, defined as a customer's overall evaluation of a product or service provider to date (Johnson \& Fornell, 1991). Grisaffe (2001) suggests that satisfaction is an indicator of met or exceeded expectations. Satisfaction is one driver of recommend and repurchase intentions. If a customer received what she or he expected, the customer is most likely to be satisfied (Reichheld, 1996). Gustafsson and Johnson (2002) note that Volvo is an example of a company with many loyal customers who spend more and more money with the company. Their findings show overall satisfaction and loyalty in Volvo's satisfaction-loyalty-performance indicator.

Jones and Sasser (1995) indicate that the link between satisfaction and loyalty is non-linear. They measured loyalty as the customer's state of intent to repurchase; they found that moving customers to a higher level of satisfaction helps to develop long-term loyalty. Olsen and Johnson (2003) found a positive relationship between satisfaction and loyalty and found that equity had a mediating effect on loyalty. They defined loyalty as a behavioral intentions construct.

Studies by Anderson, Fornell and Lehmann (1994), and Rust and Zahorik (1993) found satisfaction to be a leading factor in determining loyalty. Shamdasani and Balakrishnan (2000) examined the determinants of relationship quality and loyalty of personalized services. They found 
that trust and satisfaction significantly influence loyalty to particular service providers. McAlexander, Kim and Roberts (2003) investigated the impact of satisfaction on customer loyalty. Their empirical survey results indicate that satisfaction is a key driver of loyalty.

Soderlund and Ohman (2003) empirically studied the satisfaction-intention link with respect to different intention constructs. They suggest that the selection of one particular intention indicator over another will generate different conclusions about the role of satisfaction as a determinant of intentions.

Olsen and Johnson (2003) found a positive relationship between satisfaction and loyalty. Gustafsson and Johnson (2002) measured the satisfaction-loyalty-performance link at Volvo. They concluded that Volvo maintains a large number of loyal customers who have repeat purchases with the company. Ranaweera and Prabhu (2003) examined the combined effects of customer satisfaction and trust on customer retention and positive word of mouth (one element of loyalty). Their data from this large-scale survey confirmed that both satisfaction and trust have a strong positive association with customer retention and word of mouth.

\subsection{Trust}

The construct of trust has taken on a more important role in the marketing literature over the last decade (Morgan \& Hunt 1994; Moorman, et al., 1993; Brashear et al., 2003). Moorman et al. (1993) define trust as "a willingness to rely on an exchange partner in whom one has confidence" (p. 82). Morgan and Hunt (1994) define trust as "the belief that a party's word or promise is reliable and that the party will fulfill his or her obligations in an exchange relationship" (p. 23). Doney and Cannon (1997) define trust as "the perceived credibility and benevolence of a target" (p. 36).

Wilson (1995) states “Trust is a fundamental relationship model building block". Numerous researchers have concluded the importance of trust. Zaheer et al., (1998) found trust to have an important role in facilitating closer buyer-supplier relationships by reducing the tendency of firms to take advantage of each other. Lewicki et al., (1998) states that "Trust is critical for success in relationships involving cross-functional teams, temporary work groups, strategic alliances and socially embedded partnerships" (p. 439). Reichheld and Schefter (2000) state that "To gain the loyalty of customers, you must first gain their trust".

Brashear et al. (2003) investigate trust-building processes and outcomes in the sales managersalesperson relationship. Their results show that trust is directly related to job satisfaction and relationalism, and indirectly related to organizational commitment.

Bitner's (1995) findings confirm that loyalty to the firm increases when consumers have perceptions of trust in the service provider. Bowen and Shoemaker (2003) emphasize that benefits may be the first element of loyalty; the second major element of loyalty is trust because trust cannot be easily copied by competitors.

\subsection{Loyalty}

Loyalty is a primary goal of relationship marketing and sometimes even equated with the relationship marketing concept itself (Sheth \& Parvatiyar 1999). Jacoby and Chestnut (1978) explain that loyalty is not merely a behavior; it is a function of underlying psychological factors as well. They propose the definition of brand loyalty as " ... the biased (i.e., non-random) behavioral response (i.e. purchase) expressed over time by some decision-making unit with respect to one 
or more alternative brands out of a set of such brands and is a function of psychological (decision-making, evaluative) process". Attitudinal loyalty is "the consumer's predisposition towards a brand as a function of psychological processes" (Jacoby \& Chestnut, 1978). Drawing from the attitudinally-based approach used by Jacoby and Chestnut (1978), there are three types of information - belief structure, state of affect, and behavioral intentions - that can be represented on a continuum of learning.

There is no consensus in the marketing literature on how loyalty should be measured (Bennett \& Rundle-Thiele, 2002). Keller (1993) suggests that loyalty is present when favorable attitudes toward the brand are manifested in repeat buying behavior. Gremler and Brown (1998) state that both attitudinal and behavioral dimensions need to be incorporated into measurements of loyalty.

Evolving out of, and contradictory to, early definitions that were solely behavioral, customer loyalty today is usually viewed as comprising both behavioral and attitudinal components (Gremler \& Brown, 1998).

Grisaffe (2001) suggests that how one constructs a loyalty measurement depends upon his/her chosen theoretical position on how behavior and attitude work together, a reflective latent variable, or some other means or statistical combination of the attitudinal and behavioral components of loyalty. Gremler and Brown (1998) identify three attitudinal measures of loyalty, which are: (1) the likelihood of continuing to do business or re-purchasing, (2) the likelihood of expanding the business or purchasing, and (3) the willingness to recommend or serve as a reference.

There is a growing body of research that indicates that loyalty is developed in ways that are more dynamic and complex than reflected in the common "satisfaction builds loyalty" models (Fournier et al., 1998; Oliver, 1999). Oliver (1999) presents an evolutionary model in which satisfaction makes important contributions to the decision to repurchase early in the ownership cycle. In this model, as customers gain experience, a "convergence of product, personal, and social forces can lead to the emergence of ultimate loyalty" (p. 42).

Loyalty extends beyond simple satisfaction. Reichheld and Aspinall (1993) found that $90 \%$ of customers who changed from one supplier to another - in this case their bank - were satisfied with their original supplier. Loyalty intentions are important in marketing because they serve as predictions of consumer decision making. Loyalty intentions represent a willingness of someone, such as a customer, employee or friend, to make an investment or personal sacrifice in order to strengthen a relationship.

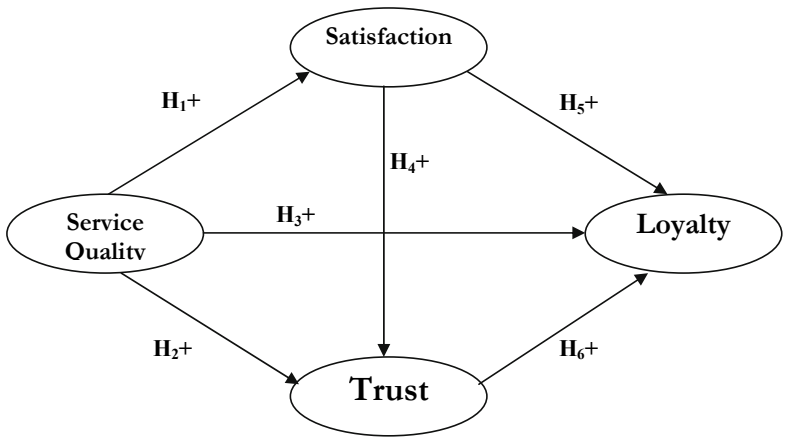

Fig. 1 - Theoretical model of the study. Source: own 
Based on previous research and theoretical review, the following hypotheses were proposed (Fig. 1):

H1: Service Quality positively influences Satisfaction.

H2: Service Quality positively influences Trust.

H3: Service Quality positively influences Loyalty.

H4: Satisfaction positively influences Trust.

H5: Satisfaction positively influences Loyalty

H6: Trust positively influences Loyalty.

\section{RESEARCH DESIGN AND PROCEDURES}

This study hypothesizes that satisfaction and trust, rather than service quality, are focal intermediate constructs in a latent structure model. Thus, in the structural equation model, service quality is an exogenous construct and satisfaction, trust and loyalty are endogenous constructs (Figure 1).

Table 1 presents the socio-demographic data, such as gender and household income per year. These data were included in the survey instrument in order to explore the characteristics of customers. The population of the study is young people who are attending their studies in Albanian universities. The sample was drawn from students of two universities in the central part of Albania. Data were collected during a two month period (February-March 2012) by personally contacting each respondent. The data collection team was comprised from students who have experience with field work and data gathering. Being themselves students made easier and more convenient for them to engage in such a study were the target population was also comprised of students. From 300 surveys distributed, only 258 of them were considered usable for further analysis (response rate $86 \%$ ).

Tab. 1 - Socio-demographic characteristics of the sample. Source: own

\begin{tabular}{|l|l|c|}
\hline \multicolumn{1}{|c|}{ Characteristics } & \multicolumn{1}{|c|}{ Categories } & Percentage \\
\hline Gender & Male & $41 \%$ \\
& Female & $59 \%$ \\
\hline \multirow{2}{*}{ Household income } & Less than 360,000 (€2,666) per year & $13 \%$ \\
& $360.001-720,000(€ 2,667-€ 5,333)$ per year & $30 \%$ \\
& $720.000-1,080,000(€ 5,334-€ 8,000)$ per year & $28 \%$ \\
& $1,080,001-1,440,000(€ 8001-€ 10,666)$ per year & $22 \%$ \\
& More than 1,140,000 $(€ 10,666)$ per year & $7 \%$ \\
\hline
\end{tabular}

The instrument was composed of 20 measurement items. The measurement items relate to the constructs of satisfaction, trust, commitment and loyalty. This study used items which have effectively measured these constructs based on their high level of reliability and validity in previous research. However, modifications have been made on certain measures to make them more appropriate for the context of this study. All constructs were operationalized by using multi-item measures. A five - point Likert scale, ranging from " $1=$ strongly disagree" to " $5=$ 
strongly agree" was used. Table 2 presents a listing of the constructs and measures employed in the study.

In this paper, the items of antecedent factors of service quality were mostly adopted from the model of SERVQUAL (Parasuraman et al., 1988; Parasuraman et al., 1991) and later studies in terms of service quality (e.g., Asubonteng et al., 1996; Cronin, 1994; Leung \& To, 2001). Customer trust was developed upon the studies of Ribbink et al. (2004), Pavlou (2003), and Genfen et al., (2003). Further, customer satisfaction and customer loyalty measures were mainly based on qualitative studies by Zeithaml et al., (1990), Parasuraman and Grewal (2000), and Ribbink et al., (2004).

Tab. 2 - Latent and manifest variables used to test the hypotheses of the study. Source: own

\begin{tabular}{|c|c|}
\hline $\begin{array}{l}\text { Latent } \\
\text { Variables }\end{array}$ & Manifest variables \\
\hline \multirow[t]{5}{*}{$\begin{array}{l}\text { Service } \\
\text { Quality (乡1) }\end{array}$} & $\begin{array}{l}\text { SEQ1: My overall opinion is that physical aspects of the store are convenient } \\
\text { and visually appealing. }\end{array}$ \\
\hline & SEQ2: My overall opinion about retailer's reliability is very positive. \\
\hline & SEQ3: My overall evaluation about staff's personal interaction is very positive. \\
\hline & SEQ4: Store's personnel are always ready to handle potential problems. \\
\hline & SEQ5: My overall opinion about store's policy is very positive. \\
\hline \multirow{5}{*}{$\begin{array}{l}\text { Satisfaction } \\
(\eta 1)\end{array}$} & SAT1: Compared to other stores, I am very satisfied with this store. \\
\hline & SAT2: Based on all my experiences with this store, I am very satisfied. \\
\hline & SAT3: I am satisfied with the price/quality ratio offered at the store. \\
\hline & SAT4: In general, I am satisfied with the service offered at this store. \\
\hline & SAT5: In general, this store offers a satisfactory assortment of products. \\
\hline \multirow[t]{5}{*}{ Trust $(\eta 2)$} & TRU1: I am sure that the staff of this store act in my best interest. \\
\hline & TRU2: I am sure that this store's personnel would do everything to satisfy me. \\
\hline & TRU3: I have great confidence in this store's staff. \\
\hline & $\begin{array}{l}\text { TRU4: I believe that the price/quality ratio offered at the store is very reason- } \\
\text { able. }\end{array}$ \\
\hline & TRU5: I consider myself loyal to this store. \\
\hline \multirow[t]{5}{*}{ Loyalty $(\eta 3)$} & LOY1: I can highly recommend this store. \\
\hline & LOY2: If I could decide again, I would choose this store again. \\
\hline & LOY3: I like to be a customer of this store. \\
\hline & LOY4: I can identify myself with this store. \\
\hline & LOY5: I will prefer this store to other stores at any time. \\
\hline
\end{tabular}




\subsection{Reliability analysis}

Reliability is conducted to assess data quality. A reliability test was used to assess consistency in measurement items. Cronbach's alpha was used to measure the internal consistency of the measurement items. The value of Cronbach's alpha should exceed 0.70 as suggested by Nunually (1978) and Hair et al., (2009). Table 3 provides the Cronbach's alphas for scale items used in this study.

Tab. 3 - Cronbach's Alpha for Scale Items. Source: own

\begin{tabular}{|l|c|c|c|}
\hline \multicolumn{1}{|c|}{ Scales } & $\begin{array}{c}\text { Number } \\
\text { of items }\end{array}$ & Sample size & Cronbach's alpha \\
\hline Service Quality & 5 & 234 & 0.934 \\
\hline Satisfaction & 5 & 234 & 0.941 \\
\hline Trust & 5 & 234 & 0.911 \\
\hline Loyalty & 5 & 234 & 0.909 \\
\hline
\end{tabular}

\subsection{Validity Analysis}

Validity is the degree to which an instrument measures what it intends to measure, and the degree to which the "think" that the instrument measures have meaning. (Lawrence \& Martin, 2001). In this study, three validity tests were used to measure the latent constructs and to ensure acceptability of the instrument (Hennig-Thurau et al., 2001; Morgan \& Hunt, 1994). These include content validity, convergent validity and discriminant validity.

Content validity is the degree to which the content of a test or questionnaire covers the extent and depth of the topics it is intended to cover. Content validity, discriminant validity and unidimensionality can be investigated by using factor analysis. Construct validity, including convergent validity and discriminant validity, assess the degree to which a measurement is represented and logically concerned.

Tab. 4 - Confirmatory Factor Analysis (CFA) results for the study. Source: own 


\begin{tabular}{|l|l|l|l|l|l|}
\hline Construct & Path & Coefficient & Std Error & $t$-value & R2 \\
\hline Service Quality & Service Quality SEQ1 & 0.047 & 0.0048 & 13.14 & 0.71 \\
& Service Quality SEQ2 & 0.063 & 0.0038 & 18.40 & 0.68 \\
& Service Quality SEQ3 & 0.055 & 0.0029 & 14.69 & 0.61 \\
& Service Quality SEQ4 & 0.061 & 0.0044 & 10.66 & 0.81 \\
& Service Quality SEQ5 & 0.048 & 0.0033 & 17.41 & 0.69 \\
\hline Satisfaction & Satisfaction SAT1 & 0.055 & 0.0037 & 16.61 & 0.68 \\
& Satisfaction SAT2 & 0.061 & 0.0037 & 15.77 & 0.77 \\
& Satisfaction SAT3 & 0.060 & 0.0041 & 15.32 & 0.80 \\
& Satisfaction SAT4 & 0.052 & 0.0033 & 14.62 & 0.75 \\
& Satisfaction S ST5 & 0.064 & 0.0042 & 16.39 & 0.68 \\
\hline Trust & Trust TRU1 & 0.048 & 0.0033 & 15.36 & 0.78 \\
& Trust TRU2 & 0.064 & 0.0037 & 14.16 & 0.61 \\
& Trust TRU3 & 0.061 & 0.0039 & 15.45 & 0.69 \\
& Trust TRU4 & 0.055 & 0.0033 & 16.14 & 0.72 \\
& Trust TRU5 & 0.059 & 0.0035 & 16.54 & 0.77 \\
\hline Loyalty & Loyalty LOY1 & 0.059 & 0.0037 & 17.94 & 0.82 \\
& Loyalty LOY2 & 0.064 & 0.0033 & 16.24 & 0.68 \\
& Loyalty LOY3 & 0.057 & 0.0039 & 18.29 & 0.80 \\
& Loyalty LOY4 & 0.066 & 0.0033 & 15.74 & 0.77 \\
& Loyalty LOY5 & 0.063 & 0.0031 & 15.64 & 0.73 \\
\hline
\end{tabular}

Discriminant validity is defined as the evidence that different methods or tests developed to measure different traits, indeed, measure different constructs. Discriminant validity is a criterion imposed on a measure of a construct requiring that it not correlate too highly with measures from which it is assumed to differ. Factor analysis was used to assess unidimensionality, convergent validity, and discriminant validity in this study.

Unidimensionality is defined as the existence of one construct underlying a set of items. Thus, unidimensionality is the degree to which items represent one and only one underlying latent variable. The concept of unidimensionality has long been recognized as one of the most basic assumptions in measurement theory. Lack of unidimensionality most often represents a misspecification and, unfortunately, a number of misspecifications of this kind typically occur with initial models. (Anderson \& Gerbing, 1982).

Since these validities were assessed by conducting factor analysis, the respective results are presented in next section.

\subsection{Confirmatory Factor Analysis}

Confirmatory factor analysis (CFA) was conducted to assess the construct validity of the model. Convergent validity is confirmation of the existence of a construct determined by the correlations exhibited by independent measures of the construct. To assess convergent validity, the loading estimates and construct reliability were investigated. In SPSS AMOS 18, convergent validity can be assessed and tested using the measurement model by determining the significant t-value of each item's estimated pattern coefficient on its posited underlying construct factor. (Anderson \& Gerbing, 1988). 
Confirmatory factor analysis (CFA) was performed using SPSS AMOS 18 to measure the unidimensionality, convergent and discriminant validity. The CFA results provide overall fit indices $\left(\chi^{2}=615.41\right)$, chi-square degree of freedom $=234$, RMSEA (root mean square error of approximation $)=0.082$, GFI (goodness-of-fit) $=0.85$, AGFI (adjusted goodness-of-fit $)=0.79$, CFI (comparative fit index) $=0.96$ RMR (root mean square residual) $=0.061$ and NNFI (nonnormed fit index $=0.96$. Table 4 presents the results of the CFA analysis, while Table 5 shows the fit statistics results.

Tab. 5 - Fit Statistics Results. Source: own

\begin{tabular}{|l|l|l|l|l|l|l|}
\hline Description & $p$-value & RMSEA & GFI & AGFI & NNFI & CFI \\
\hline Model & 0.0021 & 0.082 & 0.85 & 0.79 & 0.96 & 0.96 \\
\hline Service Quality & 0.0001 & 0.137 & 0.91 & 0.91 & 0.94 & 0.92 \\
\hline Satisfaction & 0.0024 & 0.107 & 0.95 & 0.82 & 0.96 & 0.90 \\
\hline Trust & 0.0000 & 0.143 & 0.90 & 0.83 & 0.91 & 0.97 \\
\hline Loyalty & 0.0021 & 0.042 & 0.94 & 0.94 & 0.91 & 0.93 \\
\hline
\end{tabular}

As it can be seen from table 4 , the $\mathrm{R}^{2}$ values, which explain the relative variance of the dependent variable, are satisfactory (larger than 0.60) (Joreskog \& Sorbom, 1999). So, all manifest variables are valid for further analysis through Structural Equations Modeling (SEM).

Goodness-of-fit of the final model indicated "reasonable or good fit" or RMSEA $=0.082$. Brown and Cudeck (1993) suggested that root mean square error of approximation (RMSEA) between 0.05 and 0.08 provide reasonable error of approximation. Hair et al., (2009) suggested $0.05<$ RMSEA $<0.08$ is for "good fit".

In this study, CFI (comparative fit index) $=0.96$ denoting a good fit. Hu and Bentler (1999) suggested that a rule of thumb for the CFI and the incremental indexes is that values greater than roughly 0.90 may indicate reasonably good fit of the researcher's model.

The GFI was the first standardized fit index (Joreskog \& Sorbom, 1999). GFI = 1.0 indicates perfect model fit. Therefore, a GFI $=0.85$ demonstrates reasonable fit in this study. The AGFI of 0.79 indicated an extension of the GFI.

The NNFI (non-normed fit index) or Tucker-Lewis Index has been recommended by Bentler and Bonett (1980). Hair et al., (2009) recommended a value of 0.90 or better for good fit. Thus, an NNFI $=0.96$ for this study implies good fit.

From the above goodness-of-fit evaluation, confirmatory factor analysis for the final measurement model reasonably supported the model's fit.

\section{Unidimensionality}

Unidimensionality was examined here by incorporating the four unidimensional scales into a single factor analysis. Garver and Mentzer (1999) stated that recent developments and research strongly suggest that confirmatory factor analysis (CFA) is a more rigorous and precise test for unidimensionality as compared to traditional techniques, such as exploratory factor analysis. Therefore, confirmatory factor analysis was used to identify unidimensionality in this study.

Garver and Mentzer (1999) also suggested that the criteria for assessing construct unidimension- 
ality in CFA are: 1) the overall measurement model fit, and 2) components of the measurement model fit. The overall measurement model fit or goodness-of-fit indexes of the final model have been analyzed in the previous section indicated "reasonable fit" $\left(\chi^{2}=615.41\right)$, chi-square degree of freedom $=234$, RMSEA $=0.82, \mathrm{GFI}=0.85, \mathrm{AGFI}=0.79$, CFI $=0.96$ and NNFI $=0.96$.

Components of the measurement model fit were analyzed by examining the standardized residuals. When the standardized shared residuals variance is above 2.58 - corresponding to the critical $\mathrm{p}<0.01$ threshold - one or both of the measurement items may not be unidimensional. (Gerbing \& Anderson, 1988; Segar, 1997). In this study, all the standardized residuals of the model were below the critical value of 2.58 , so the model could be judged to be unidimensional.

\section{Convergent validity}

Convergent validity can be empirically assessed by reviewing the t-tests for the factor loadings. If all factor loadings for the indicators measuring the same construct are statistically significant (greater than twice their standard error), this can be viewed as evidence supporting the convergent validity of those indicators. (Anderson \& Gerbing, 1988) As shown in Table 4, all t-tests were significant showing that all indicators are effectively measuring the same construct, or have high convergent validity.

\section{Discriminant validity}

As it can be seen from Table 6, the average communalities (or Average Variance Extracted AVE) measures of each construct are greater than the variance shared with other constructs, demonstrating that the discriminant validity of all scales is adequate. In addition, all AVE exceed 0.50 , indicating solid the construct validity. Overall, the measurement results are satisfactory and suggest that it is appropriate to proceed with the evaluation of the structural model.

Tab. 6 - Correlation coefficients between latent variables of the model and the Average Variance Extracted values. Source: own

\begin{tabular}{|l|c|c|c|c|c|}
\hline & Service Quality & Satisfaction & Trust & Loyalty & AVE \\
\hline Service Quality & 1.00 & & & & 0.87 \\
\hline Satisfaction & 0.64 & 1.00 & & & 0.73 \\
\hline Trust & 0.58 & 0.49 & 1.00 & & 0.84 \\
\hline Loyalty & 0.61 & 0.55 & 0.51 & 1.00 & 0.81 \\
\hline
\end{tabular}

The p-value are all less than 0.01 .

Fig. 2 - The Structural Equation Modeling of the Study. Source: own 


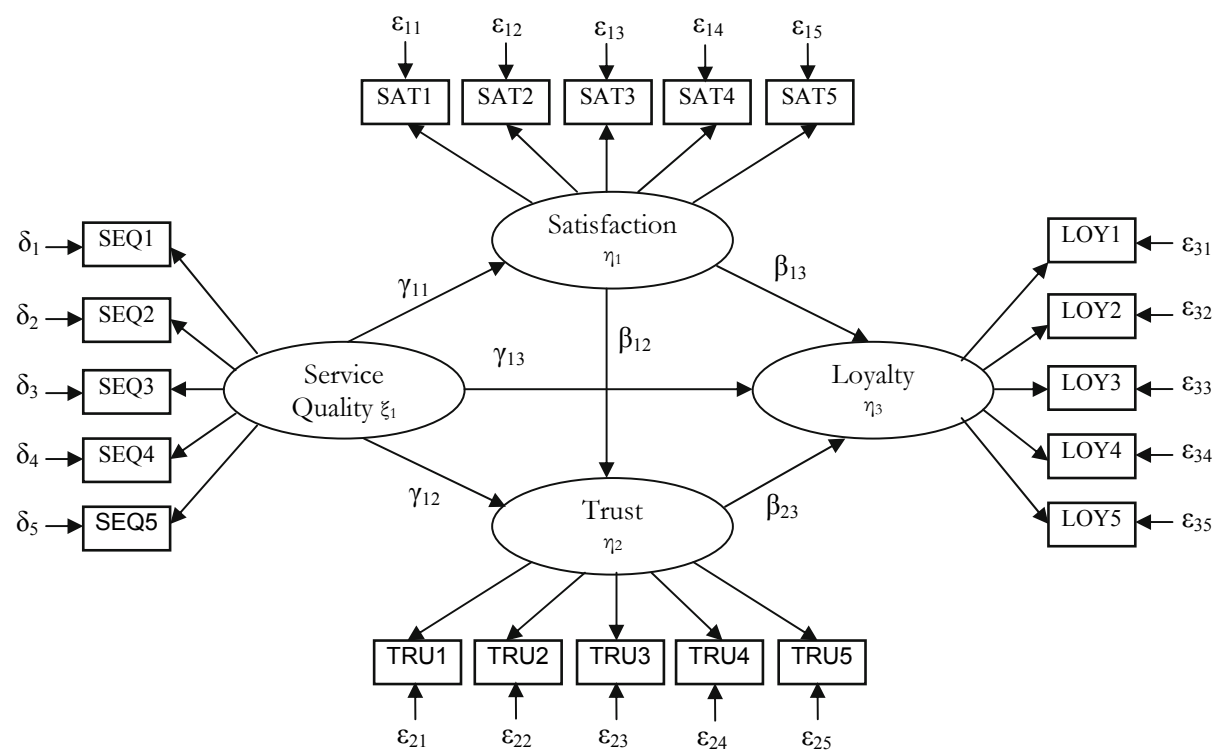

\section{HYPOTHESES TESTING RESULTS}

The hypothesized relationships in the model are examined using structural equation modeling (SEM). The hypothesized structural equation modeling was tested using SPSS AMOS 18. Results are shown on Table 7. All the hypotheses were supported.

Tab. 7 - Structural equation results for the hypothesized model. Source: own

\begin{tabular}{|l|c|c|c|c|c|}
\hline \multicolumn{1}{|c|}{ Path } & Hypotheses & $\begin{array}{c}\text { Coefficient } \\
\text { estimate }\end{array}$ & $\begin{array}{c}\text { Std } \\
\text { Error }\end{array}$ & $t$-value & $p$-value \\
\hline Service Quality => Satisfaction & H1 & 0.57 & 0.08 & 5.38 & $<0.001$ \\
\hline Service Quality => Trust & H2 & 0.37 & 0.07 & 8.49 & $<0.001$ \\
\hline Service Quality => Loyalty & H3 & 0.23 & 0.06 & 3.68 & $<0.001$ \\
\hline Satisfaction => Trust & H4 & 0.31 & 0.07 & 3.22 & $<0.005$ \\
\hline Satisfaction => Loyalty & H5 & 0.66 & 0.06 & 11.02 & $<0.001$ \\
\hline Trust => Loyalty & H6 & 0.29 & 0.07 & 4.64 & $<0.005$ \\
\hline
\end{tabular}

H1: Service Quality positively influences Satisfaction $\left(\gamma_{11}=0.57 ; \mathrm{p}<0.001\right)$. This supports the findings of Olsen, (2002); Gustafsson et al., (2005), Olorunniwo and Hsu, (2006); Rigopoulou et al., (2008), who found that service quality has a significant impact on satisfaction.

H2: Service Quality positively influences Trust $\left(\gamma_{12}=0.37, \mathrm{p}<0.001\right)$. This result confirms the belief that the higher the service quality customers receive from a service provider, the higher the trust he/she exert towards this service provider. This supports Su et al., (2009), who found that service quality impacted trust in long term relationships. It is expected that if others research this in the future they should obtain similar results.

H3: Service Quality positively influences Loyalty $\left(\gamma_{13}=0.23\right.$; $\left.\mathrm{p}<0.001\right)$. This finding comply with the research conducted by Su et al., 2009; Pollack, 2009; Yavas \& Babakus, 2009), who 
found that higher levels of service quality lead to higher levels of customers loyalty.

H4: Satisfaction positively influences Trust $\left(\beta_{12}=0.31 ; \mathrm{p}<0.005\right)$. This finding supports the previous research on the mediating role that satisfaction plays in the Service Quality - Trust relationship conducted by Fullerton and Taylor (2002); and Kantsperger and Kunz, (2010).

H5: Satisfaction positively influences Loyalty $\left(\beta_{13}=0.66\right.$; $\left.\mathrm{p}<0.001\right)$, complying with the results of many other studies (e.g., Allen, 2004; Walsh et al., 2008; Torres-Moraga et al., 2008).

H6: Trust positively influences Loyalty $\left(\beta_{23}=0.29 ; \mathrm{p}<0.005\right)$. Results from the test of Hypothesis 6 confirm the belief that the higher the level of trust the greater the loyalty intentions of young retail customers. The results support those found in previous studies. (e.g. Moorman, Deshpande, \& Zaltman, 1993; Morgan \& Hunt, 1994, Binninger, 2008; Auh, 2005; Ball et al., 2004).

\section{CONCLUSIONS, IMPLICATIONS AND LIMITATIONS}

While several authors have emphasized the multidimensional nature of service quality and the relationships between customer satisfaction, customer trust, and customer loyalty, this research sought to establish the bridges between service quality, customer satisfaction, customer trust, and customer loyalty in a retail context.

Empirical tests of the model, using a sample of young retail customers, were conducted to support the proposed hypotheses.

This research contributes to the progress of formulating and measuring the constructs of service quality, satisfaction, trust and loyalty. Similarly, the items measuring these constructs in the retailing setting were tested and refined. The reliable and valid instrument confirmed in this research can be used by further studies detecting the relationships among these constructs in an extended context.

The findings also provide several managerial implications. The fundamental premise of the proposed model was that retailers should understand comprehensively the critical factors necessary to achieve high service quality that will significantly impact on customers' trust, satisfaction and loyalty, and use them as diagnostic information. By recognizing and analyzing these diagnostic indicators, retailers will be better able to formulate and implement their strategic plans. According to Hansen and Bush (1999), a great success will result from a strategy that concentrates on one targeted dimension of service quality, rather than from one in which the retail firm improves marginally on all of the dimensions. The interpretation of the research model has the potential to help retailers better understand how customers assess the quality of service and how their service campaigns influence customer satisfaction, trust and loyalty in different extent. Learning the uncovered relationships between service quality and customer satisfaction, trust, and loyalty, retailers can effectively allocate their resources and develop a rational plan to improve their service quality under specific business circumstances.

Although the results presented in this study are useful in understanding the relationships between service quality and consumer behavioral factors (satisfaction, trust, and loyalty), there exist several limitations that need to be addressed. Firstly, the sampling frame includes university students. This may lead to loss of generalizability, since young students comprise only a part 
of the whole retail customers' population. Although the sample used appears homogenous and yielded reliable data, it would be better to include more demographic control variables, which lead to more generalizable results and allow for possible segmentation in terms of consumers' perceptions of service quality, satisfaction, trust, and loyalty. Further studies should use a more representative sample of whole retail customers' population, which lead to more sound and comprehensive findings. Secondly, the depend variables in the hypothesized model, i.e. satisfaction, trust, and loyalty, are likely to be influenced by other variables other than service quality, which were not object of this research. So, other factors that are found to influence loyalty are brand name and value and brand commitment (Kuikka \& Laukkanen, 2012; Belaid \& Behi, 2011); confidence benefits and special treatments benefits (Ruiz-Molina et al., 2009); the quality of product offered in retail outlets (Allaway et al., 2011; Fandos \& Flavián, 2006). Other studies identify factors such as price (Martin-Consuegra et al., 2007) or store enviroment (Guenzi et al., 2006) as factors influencing customer trust and satisfaction. Addressing these additional factors in specific retailing contexts extend the landscape of retailing research and can contribute in achieving deeper insights on retail customer behavior.

\section{References}

1. Aaker, J. L. (1997). Dimensions of brand personality. Journal of Marketing Research, 34(3), 347356. http://dx.doi.org/10.2307/3151897

2. Allaway, A. W., Huddleston, P., Whipple, J. \& Ellinger, A. E. (2011). Customer-based brand equity, equity drivers, and customer loyalty in the supermarket industry. Journal of Product \& Brand Management, 20(3), 190-204. http://dx.doi.org/10.1108/10610421111134923

3. Allen, D. R. (2004). Customer satisfaction research management: A comprehensive guide to integrating customer loyalty and satisfaction metrics in the management of complex organizations. Milwaukee, Wisconsin: ASQ Quality Press.

4. Anderson, E. W., Fornell, C. \& Lehmann, D. R. (1994). Customer satisfaction, market share, and profitability: Findings from Sweede. Journal of Marketing, 58(3), 53-66. http:// dx.doi.org/10.2307/1252310

5. Anderson, J. C. \& Gerbing, D.W. (1982). Some methods for respecifying measurement models to obtain unidimensional construct measurement. Journal of Marketing Research, 9(4), 453-460. http://dx.doi.org/10.2307/3151719

6. Anderson, J. \& Gerbing, W. (1988). Structural equation modeling in practice: A review and recommended two stage approach. Psychological Bulletin, 103(3), 411-423. http://dx.doi. org/10.1037//0033-2909.103.3.411

7. Asubonteng, P., McCleary, K. \& Swan, J. (1996). SERVQUAL revisited: a critical review of service quality. Journal of Services Marketing, 10(6), 62-68. http://dx.doi.org/10.1108/0887604 9610148602

8. Auh, S. (2005). The effects of soft and hard service attributes on loyalty: the mediating role of trust. Journal of Services Marketing, 19(2), 80-92. http://dx.doi.org/10.1108/08876040510591394

9. Ball, D., Coelho, P. S. \& Machás, A. (2004). The role of communication and trust in explaining customer loyalty: An extension to the ECSI model. European Journal of Marketing, 
38(9/10), 1272-1293. http://dx.doi.org/10.1108/03090560410548979

10. Belaid, B. \& Behi, A. T. (2011). The role of attachment in building consumer-brand relationships: an empirical investigation in the utilitarian consumption context. Journal of Product \& Brand Management, 20(1), 37-47. http://dx.doi.org/10.1108/10610421111108003

11. Bennett, R. \& Rundle-Thiele, S. (2002). A comparison of attitudinal loyalty measurement approach. Journal of Brand Management, 9(3), 193-207. http://dx.doi.org/10.1057/palgrave. bm.2540069

12. Bentler, P. M. \& Bonett, D.G. (1980). Significance tests and goodness of fit in analysis of covariance structures. Psychological Bulletin, 88(3), 588-606. http://dx.doi.org/10.1037//00332909.88.3.588

13. Binninger, A.S. (2008). Exploring the relationships between retail brands and consumer store loyalty. International Journal of Retail \& Distribution Management, 36(2), 94-110. http:// dx.doi.org/10.1108/09590550810853057

14. Bitner, M.J. (1995). Building service relationships: It's all about promises. Journal of the Academy of Marketing Science, 23(4), 246-251. http://dx.doi.org/10.1177/009207039502300403

15. Bolton, R. N. (1998). A dynamic model of the duration of the customers' relationship with a continuous service provider: The role of customer satisfaction. Marketing Science, 17(1), 45 65. http://dx.doi.org/10.1287/mksc.17.1.45

16. Bolton, R. N. \& Drew, J. H. (1991). A multistage model of customers' assessments of service quality and value. Journal of Consumer Research, 17(4), 375-384. http://dx.doi. org/10.1086/208564

17. Bowen, D. E. \& Cummings, T. G. (1990). Suppose we took service seriously? in D. E. Bowen, R. B. Chase \& T. G. Cummings (Eds.), Service Management Effectiveness: Balancing Strategy, Organization, and Human Resources, Operations, and Marketing (pp. 1-14). Jossey Bass.

18. Bowen, J. T. \& Shoemaker, S. (2003). Loyalty: a strategic commitment. Cornell Hotel and Restaurant Administration, 44(5/6), 31-45. http://dx.doi.org/10.1016/S0010-804(03)90105-4

19. Brashear, T. G., Boles, J. S., Bellenger, D. N. \& Brooks, C. M. (2003). An empirical test of trust-building processes and outcomes in sales manager - salesperson relationships. Journal of the Academy of Marketing Science, 31(2), 189-200. http://dx.doi.org/10.1177/0092070302250 902

20. Browne, M.W. \& Cudeck, R. (1992). Alternative ways of assessing model fit. Sociological Method and Research, 21(2), 230-258. http://dx.doi.org/10.1177/0049124192021002005

21. Carmen, J. M. \& Langeard, E. (1980). Growth strategies for services firms. Strategic Management Journal, 1(1), 7-22. http://dx.doi.org/10.1002/smj.4250010103

22. Cronin, J. J. \& Taylor, S.A. (1994). SERVPERF versus SERVQUAL: reconciling performance-based and perceptions-minus-expectations measurement of service quality. Journal of Marketing, 58(1), 125-131. http://dx.doi.org/10.2307/1252256

23. Crosby, P. B. (1979). Quality is free: the art of making quality certain. McGraw-Hill, New York.

24. Deutsch, M. (1958). Trust and suspicion. Journal of Conflict Resolution, 2(4), 265-279. http:// dx.doi.org/10.1177/002200275800200401 
25. Dick, A.S. \& Basu, K. (1994). Customer loyalty: toward an integrated conceptual framework. Journal of the Academy of Marketing Science, 22(2), 99-113. http://dx.doi.org/10.1177/0092 070394222001

26. Doney, P. M. \& Canon, J. P. (1997). An examination of the nature of trust in buyer-seller relationships. Journal of Marketing, 61(2), 35-51. http://dx.doi.org/10.2307/1251829

27. Fandos, C. \& Flavián, C. (2006). Intrinsic and extrinsic quality attributes, loyalty and buying intention: an analysis for a PDO product. British Food Journal, 108(8), 646-662. http:// dx.doi.org/10.1108/00070700610682337

28. Fornell, C. \& Larcker, D. F. (1981). Evaluating structural equation models with unobservable variables and measurement error. Journal of Marketing Research, 18(1), 39-50. http://dx.doi. org $/ 10.2307 / 3151312$

29. Fournier, S., Dobscha, S. \& Mick, D.G. (1998). Preventing the premature death of relationship marketing. Harvard Business Review, 76(1), 42-51.

30. Fullerton, G. \& S. Taylor (2002). Mediating, interactive and non-linear effects in service quality and satisfaction with services research. Canadian Journal of Administrative Sciences, 19(2), 124-136. http://dx.doi.org/10.1111/j.1936-4490.2002.tb00675.x

31. Garver, M. S. \& Mentzer, J. T. (1999). Logistics Research Methods: Employing Structural Equation Modeling to Test for Construct Validity. Journal of Business Logistics, 20(1), 33-57.

32. Garvin, D. A. (1983). Quality on the line. Harvard Business Review, 61 (September - October), 65-73.

33. Gefen, D., Karahanna, E. \& Straub, D.W. (2003). Trust and TAM in Online Shopping: An Integrated Model. MIS Quarterly, 27(1), 51-90.

34. Gerbing, D. W. \& Anderson, J. C. (1988). An update paradigm for scale development incorporating unidimensionality and its assessment. Journal of Market Research, 25(2), 186-192. http://dx.doi.org/10.2307/3172650

35. Gremler, D. D. \& Brown, S. W. (1998). Service loyalty: antecedents, components and outcomes. Conference Proceeding, 9, 165-166. American Marketing Association.

36. Grisaffe, D. (2001). Loyalty - attitude, behavior, and good science: a third take on NealBrandt debate. Journal of Consumer Satisfaction, Dissatisfaction and Complaining Behavior, 14, 55-59.

37. Gronroos, C. (1984). A service quality model and its marketing implications. European Journal of Marketing, 18(4), 36-44. http://dx.doi.org/10.1108/EUM0000000004784

38. Gronroos, C. (1990). Relationship approach to marketing in service contexts. Journal of Business Research, 20(1), 3-11. http://dx.doi.org/10.1016/0148-2963(90)90037-E

39. Guenzi, P., Johnson, M. D. \& Castaldo,S. (2009). A comprehensive model of customer trust in two retail stores. Journal of Service Management, 20(3), 290 - 316. http://dx.doi. org/10.1108/09564230910964408

40. Gummesson, E. (1998). Productivity, quality and relationship marketing in service operations. International Journal of Contemporary Hospitality Management, 10(1), 4-15. http://dx.doi. org/10.1108/09596119810199282

41. Gustafsson, A. \& Johnson, M. D. (2002). Measuring and managing the satisfaction-loyalty-performance links at Volvo. Journal of Targeting, Measurement and Analysis, 10(3), 249-258. 
http://dx.doi.org/10.1057/palgrave.jt.5740050

42. Gustafsson, A., Johnson, M. D. \& Roos, I. (2005). The effects of customer satisfaction, relationship commitment dimensions, and triggers on customer retention. Journal of Marketing, 69(4), 210-218. http://dx.doi.org/10.1509/jmkg.2005.69.4.210

43. Hair, J. F., Black, W. C., Babin, B. J. \& Anderson, R. E. (2009). Multivariate data analysis. New Jersey: Prentice Hall. http://dx.doi.org/10.1016/j.csda.2008.11.030

44. Hansen, E. \& Bush, R. J. (1999). Understanding customer quality requirements: model and application. Industrial Marketing Management, 28(2), 119-130. http://dx.doi.org/10.1016/ S0019-8501(98)00007-8

45. Hennig-Thurau, T., Langer, M. F. \& Hansen, U. (2001). Modeling and managing loyalty. Journal of Service Research, 3(4), 331-343. http://dx.doi.org/10.1177/109467050134006

46. Hu, L. T. \& Bentler, P. M. (1999). Cutoff criteria for fit indexes in covariance structure analysis: Conventional criteria versus new alternatives. Structural Equation Modeling: A Multidisciplinary Journal, 6(1), 1-55. http://dx.doi.org/10.1080/10705519909540118

47. Jacoby, J. \& Chestnut, R. (1978). Brand Loyalty: Measurement and Management. New York: Wiley.

48. Johnson, M. D. \& Fornell, C. (1991). A framework for comparing customer satisfaction across individuals and product categories. Journal of Economic Psychology, 12(2), 267-286. http://dx.doi.org/10.1016/0167-4870(91)90016-M

49. Jones, T. O. \& Sasser, W. E. (1995). Why satisfied customers defect. Harvard Business Review, 73(6), 88-99.

50. Joreskog, K.G. \& Sorbom, D. (1999). LISREL 8.54. Chicago: Scientific Software International.

51. Kantsperger, R. \& Kunz, W. H. (2010). Consumer trust in service companies: a multiple mediating analysis. Managing Service Quality, 20(1) 4-25. http://dx.doi.org/10.1108/0960452 1011011603

52. Keller, K. L. (1993). Conceptualizing, measuring, and managing customer based brand loyalty. Journal of Marketing, 57(1), 1-22. http://dx.doi.org/10.2307/1252054

53. Kuikka, A. \& Laukkanen, T. (2012). Brand loyalty and the role of hedonic value. Journal of Product \& Brand Management, 21(7), 529-537.

54. Lawrence, G. \& Martin, C. (2001). Building people, building programs. Center for Applications of Psychological Type.

55. Leung, C. \& To, C. K. (2001). Measuring perceived service quality of fashion stores: A test-retest reliability investigation. Journal of Fashion Marketing and Management, 5(4), 324-329. http://dx.doi.org/10.1108/EUM0000000007294

56. Lewicki, R. J., Mcallister, D. J. \& Bies, R. J. (1998). Trust and distrust: new relationships and realities. Academy of Management Review, 23(3), 438-458. http://dx.doi.org/10.5465/ AMR.1998.926620

57. Lovelock, C. (2000). Services Marketing: People, Technology, Strategy. New Jersey: Prentice Hall.

58. Martín-Consuegra, D., Molina, A. \& Esteban, Á. (2007). An integrated model of price, satisfaction and loyalty: an empirical analysis in the service sector. Journal of Product \& Brand 
Management, 16(7), 459-468. http://dx.doi.org/10.1108/10610420710834913

59. McAlexander, J. H., Kim, S.K. \& Roberts, S. D. (2003). Loyalty: the influences of satisfaction and brand community integration. Journal of Marketing Theory and Practice, 11(4), 1-11.

60. Moorman, C., Deshpande, R. \& Zaltman, G. (1993). Factors affecting trust in market research relationships. Journal of Marketing, 57(1), 81-101. http://dx.doi.org/10.2307/1252059

61. Morgan, R. M. \& Hunt, S. D. (1994). The Commitment-Trust Theory of Relationship Marketing. Journal of Marketing, 58(3), 20-38. http://dx.doi.org/10.2307/1252308

62. Nunnally, J. C. (1978). Psychometric theory. New York: McGraw-Hill.

63. Oliver, R. L. (1999). Whence consumer loyalty? Journal of Marketing, 63, 33-44. http://dx.doi. org/10.2307/1252099

64. Olorunniwo, F. \& Hsu, M. K. (2006). A typology analysis of service quality, customer satisfaction and behavioral intentions in mass services. Managing Service Quality, 16(2), 106-123. http://dx.doi.org/10.1108/09604520610650600

65. Olsen, L. L. \& Johnson, M. D. (2003). Service equity, satisfaction, and loyalty: From transaction-specific to cumulative evaluation. Journal of Service Research, 5(3), 184-194. http:// dx.doi.org/10.1177/1094670502238914

66. Olsen, S. O. (2002). Comparative evaluation and the relationship between quality, satisfaction and repurchase loyalty. Journal of the Academy of Marketing Science, 30(3), 240-249. http:// dx.doi.org/10.1177/00970302030003005

67. Parasuraman, A. \& Grewal, D. (2000). The impact of technology on the quality-value-loyalty chain: A research agenda. Journal of the Academy of Marketing Science, 28(1), 168-175. http:// dx.doi.org/10.1177/0092070300281015

68. Parasuraman, A., Zeithaml, V. A. \& Berry, L. L. (1985). A conceptual model of service quality and its implications for future research. Journal of Marketing, 49(3), 41-50. http:// dx.doi.org/10.2307/1251430

69. Parasuraman, A., Zeithaml, V. A. \& Berry, L. L. (1988). SERVQUAL: A multiple-item scale for measuring consumer perceptions of service quality. Journal of Retailing, 64(1), 12-40.

70. Parasuraman, A., Zeithaml, V. A. \& Berry, L. L. (1991). Refinement and reassessment of the SERVQUAL scale", Journal of Retailing, 67(4), 420-450.

71. Pavlou, P. A. (2003). Consumer acceptance of electronic commerce: Integrating trust and risk with the technology acceptance model. International Journal of Electronic Commerce, 7(3), 101-134.

72. Pollack, B. L. (2009). Linking the hierarchical service quality model to customer satisfaction and Loyalty. Journal of Services Marketing. 23(1), 42-50. http://dx.doi.org/10.1108/088760 40910933084

73. Qin, S., Li, Z. \& Xu Yi. (2009). Impacts of customer service on relationship quality: an empirical study in China. Managing Service Quality. 19(4), 391-409. http://dx.doi.org/10.1108/ 09604520910971520

74. Raj, S. P. (1985). Striking a balance between brand "popularity" and brand loyalty. Journal of Marketing, 49, 53-59. http://dx.doi.org/10.2307/1251175 
75. Ranaweera, C. \& Prabhu, J. (2003). On the relative importance of customer satisfaction and trust as determinants of customer retention and positive word of mouth. Journal of Targeting, Measurement and Analysis, 12(1), 82-90. http://dx.doi.org/10.1057/palgrave.jt.5740100

76. Reichheld, E, E. \& Sasser, W. E. (1990). Zero defections: Quality comes to services. Harvard Business Review, 68(5), 105-111.

77. Reichheld, E. E. \& Schefter, P. (2000). E-Loyalty: Your secret weapon on the Web. Harvard Business Review, 78(4), 105-113.

78. Reichheld, F. F. \& Aspinall, K. (1993). Building high-loyalty business systems. Journal of Retail Banking, 15(4), 21-29.

79. Reichheld, F. F. (1996). Learning from customer defection. Harvard Business Review, 74(2), 56-67.

80. Ribbink, D., van Riel, A. C. R., Liljander, V. \& Streukens, S. (2004). Comfort your online customer: quality, trust and loyalty on the Internet. Managing Service Quality, 14(6), 446-456. http://dx.doi.org/10.1108/09604520410569784

81. Rigopoulou, I. D. Chaniotakis, I. E., Lymperopoulos, C. \& Siomkos, G. I. (2008). Aftersales service quality as an antecedent of customer satisfaction: The case of electronic appliances. Managing Service Quality, 18(5), 512-527. http://dx.doi.org/10.1108/09604520810 898866

82. Ruiz-Molina, M.-E., Gil-Saura, I. \& Berenguer-Contrí, G. (2009). Relational benefits and loyalty in retailing: an inter-sector comparison. International Journal of Retail \& Distribution Management, 37(6), 493-509. http://dx.doi.org/10.1108/09590550910956232

83. Rust, R. T. \& Zahorik, A.J. (1993). Customer satisfaction, customer retention, and market share. Journal of Retailing, 69(2), 193-121. http://dx.doi.org/10.1016/0022-4359(93)90003-2

84. Rust, R. T., Zahorik, A. J. \& Keiningham, T. L. (1995). Return on quality (ROQ): Making service quality financially accountable. Journal of Marketing, 59(2), 58-70. http://dx.doi. org/10.2307/1252073

85. Schurr, P. H. \& Ozanne, J. L. (1985). Influence on exchange processes: Buyers' preconceptions of a seller's trustworthiness and bargaining toughness. Journal of Consumer Research, 11(4), 939-953. http://dx.doi.org/10.1086/209028

86. Segar, A. (1997). Assessing the unidimensionality of measurement: A paradigm and illustration within the context of information systems research. Omega, 25(1), 107-121. http:// dx.doi.org/10.1016/S0305-0483(96)00051-5

87. Shamdasani, P. N. \& Balakrishnan, A. A. (2000). Determinants of relationship quality and loyalty in personalized services. Asia Pacific Journal of Management, 17(3), 189-200. http:// dx.doi.org/10.1023/A:1015834214570

88. Sheth, J. N. \& Parvatiyar, (1999). The evolution of relationship marketing. In J. N Sheth, \& A. Parvatiyar (Eds.) Handbook of Relationship Marekting, (pp. 119 - 148). Sage Publications, Inc.

89. Shostack L. G. (1977). Breaking free from product marketing. Journal of Marketing, 41(2), 73 80. http://dx.doi.org/10.2307/1250637

90. Soderlund, M. \& Ohman, N. (2003). Behavioral intentions in satisfaction research revisited. Journal of Consumer Satisfaction, Dissatisfaction and Complaining Behavior, 16, 53-65. 
91. Sureshchander, G .S., Rajendran, C. \& Anatharaman, R. N. (2002). The relationship between service quality and customer satisfaction: a factor specific approach. Journal of Services Marketing, 16(4), 363-379. http://dx.doi.org/10.1108/08876040210433248

92. Torres-Moraga, E., Vásquez-Parraga, A. Z. \& Zamora-González, J. (2008). Customer satisfaction and loyalty: start with the product, culminate with the brand. Journal of Consumer Marketing, 25(5), 302-313. http://dx.doi.org/10.1108/07363760810890534

93. Walsh, G., Evanschitzky, H. \& Wunderlich, M. (2008). Identification and analysis of moderator variables: Investigating the customer satisfaction-loyalty link. European Journal of Marketing, 42(9/10), 977-1004. http://dx.doi.org/10.1108/03090560810891109

94. Wilson, D. T. (1995). An integrated model of buyer-seller relationships. Journal of Academy of Marketing Science, 23(4), 335-345. http://dx.doi.org/10.1177/009207039502300414

95. Yavas, U. \& Babakus, E. (2009). Retail store loyalty: a comparison of two customer segments. International Journal of Retail \& Distribution Management, 37(6), 477-492. http://dx.doi. org/10.1108/09590550910956223

96. Zaheer, A., Mcevily, B. \& Perrone, V. (1998). Does trust matter? Exploring the effects of inter organizational and interpersonal trust on performance. Organization Science, 9(2), 123142. http://dx.doi.org/10.1287/orsc.9.2.141

97. Zeithaml V. A. (1981). How Consumer Evaluation Processes Differ between Goods and Services. Reprinted in Lovelock, C. (1991). Services Marketing. Prentice Hall: Upper Saddle River, New Jersey.

98. Zeithaml, V. A., Berry, L. L. \& Parasuraman A. (1996). The Behavioral Consequences of Service Quality. Journal of Marketing, 60(2), 31-46. http://dx.doi.org/10.2307/1251929

99. Zeithaml, V. A., Parasuraman, A. \& Berry, L. L. (1990). Delivering quality services. New York: The Free Press.

\section{Contact information}

Shpëtim Cerri

Faculty of Economics, University "Aleksandër Xhwvani"

Elbasan, Albania

E-mail:cerri_shpetim@yahoo.com

JEL Classification: M31 